\title{
Papillary thyroid carcinoma after recombinant GH therapy for Turner syndrome
}

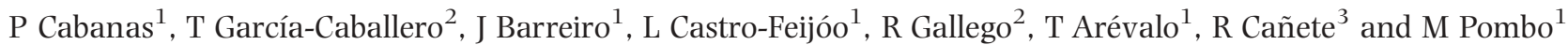 \\ ${ }^{1}$ Pediatric Endocrinology, Growth and Adolescence Unit, Department of Pediatrics and ${ }^{2}$ Department of Morphological Sciences, Faculty of Medicine, \\ Clinical University Hospital, University of Santiago de Compostela, Spain and ${ }^{3}$ Pediatric Endocrinology Unit, Department of Pediatrics, Reina Sofía \\ Clinical University Hospital, Córdoba, Spain
}

(Correspondence should be addressed to M Pombo; Email: pdmapoar@usc.es)

\begin{abstract}
Turner syndrome (TS) has been included for several years among the indications for GH treatment, generally with satisfactory outcomes. Nevertheless, the long-term effects of this treatment in non-GH deficient patients are not fully known. The incidence of thyroid carcinoma is rare in patients during childhood, it is unusual to find this neoplasia in children under sixteen years old. This article reports the cases of two Spanish patients with papillary thyroid carcinoma after GH treatment for TS. Recent studies have indicated a possible relationship between the GH-IGF axis and the pathogenesis of neoplasias, questioning the chance association of these two pathologies. In line with this, we detected GH receptor expression in the papillary carcinoma cells. Long-term prospective studies are required to clarify the possible effects of $\mathrm{GH}$ treatment on the risk of neoplasia.
\end{abstract}

European Journal of Endocrinology 153 499-502

\section{Introduction}

Turner syndrome (TS) is a chromosomal alteration due to the absence or structural anomaly of one $\mathrm{X}$ chromosome, its incidence is about $1 / 2000-2500$ in females. Patients show a particular phenotype, characterized by retarded growth and gonadal dysgenesis. Several studies have documented that TS patients show increased morbidity due to disorders including: metabolic and thyroid disturbances, ischemic cardiopathy and arterial hypertension (1-3). However, the risk of cancer, except cancer of the large bowel and gonadoblastoma in patients with occult $\mathrm{Y}$ chromosome sequences, does not seem to be increased $(1-3)$. The papillary thyroid carcinoma has not been observed among women with TS.

TS has been included for several years among the indications for growth hormone (GH) treatment, generally with satisfactory outcomes (1). Nevertheless, the long-term effects of this treatment in non-GH deficient patients are not fully known.

Recent studies have suggested a possible relationship between the GH-insulin-like growth factor-I (IGF-I) axis and the pathogenesis of neoplasias (prostate, breast, colon, lung and bladder), though the mechanisms of this putative effect have not been established $(4-7)$.

Here we report two cases of papillary thyroid carcinoma in patients who had undergone GH treatment for TS. Thyroid carcinoma is a rare neoplasia during childhood, with an incidence of only 0.02$0.3 / 100000$ in children under 16 years (8). Thus it is possible that the co-occurrence of this carcinoma with TS is not a chance association.

\section{Patients}

\section{Patient 1}

A girl aged 11 years 10 months from northern Spain, diagnosed in the neonatal period as having TS (karyotype $45 \mathrm{XO}$, without Y chromosome fragments), aortic coarctation and bicuspid aortic valve. At age 14 months diagnostic catheterism and aortoplasty were performed, with good subsequent course. There was no family history of thyroid problems or malignancies and no history of exposure to environmental ionizing irradiation. Hormone study showed IGF-1 $96.15 \mathrm{ng} / \mathrm{ml}$ (range: 173-846); IGF-binding protein$30.71 \mu \mathrm{g} / \mathrm{ml}$ (range: $2-4$ ); and L-dopa provocative test $38.8 \mathrm{ng} / \mathrm{ml}$. At age 5 years and 7 months (height SDS: 0.19 (Turner)), treatment with recombinant human GH was started at a daily dose of $0.048 \mathrm{mg} / \mathrm{kg}$, with good growth response (height SDS: 2.02). During follow-up, palpation detected a nodule in the left thyroid lobe. Biochemical analysis showed normal levels of thyroid hormones, absence of antithyroid antibodies, thyroglobulin $193 \mathrm{ng} / \mathrm{ml}$ (refer- 
ence range: $0-80$ ), and IGF-1 259 ng/ml (range: $110-$ 565). A thyroid echogram showed a left thyroid tumor and clavicle lymph nodes. Fine-needle aspiration biopsy (FNAB) findings were compatible with the diagnosis of papillary thyroid carcinoma. Total thyroidectomy and lymphadenectomy were performed, confirming this diagnosis (stage T2N1bM0), GH treatment was withdrawn.

\section{Patient 2}

A female from southern Spain, diagnosed with TS (karyotype $45 \mathrm{XO}$ ) at age 8 years. She had no family history of thyroid problems or malignancies, and no history of exposure to ionizing irradiation. Six months later (height SDS: -0.59 (Turner)) treatment with GH was started with a daily dose of $0.025-0.03 \mathrm{mg} / \mathrm{kg}$, with good growth response (height SDS: 1.73). The GH treatment was stopped at age 13 years 10 months in view of completion of growth. During GH treatment, serum IGF-I levels remained normal. Thereafter, antithyroid antibodies were detected, though thyroid function was normal. A routine follow-up at age 21 showed thyrotropin $28.88 \mathrm{mU} / \mathrm{l}$ and free thyroxine $0.6 \mathrm{ng} / \mathrm{dl}$. Thyroid gammagraphy revealed cold thyroid nodules in both lower poles, and a sonogram showed nodules and microcalcifications. FNAB was suggestive of papillary thyroid carcinoma. Total thyroidectomy with left lymphadenectomy was performed, and histopathological studies confirmed the diagnosis of thyroid carcinoma stage T2NOMO and Hashimoto's thyroiditis.

\section{Study of GH receptor expression in tumoral cells}

GH receptor expression in papillary carcinoma cells from both patients was studied by immunohistochemistry. Sections $5 \mu \mathrm{m}$ thick were mounted on Histobond adhesion Micro slides (Marienfeld, Lauda-Königshofen, Germany), dewaxed and rehydrated. For immunohistochemical staining, sections were incubated for $1 \mathrm{~h}$ at room temperature in MAb 263 anti-GH receptor (a generous gift from Dr M Waters, University of Queensland, Australia) diluted 1/250 in Dako ChemMate antibody diluent (DakoCytomation, Glostrup, Denmark). The dextran polymer detection method was employed by using the EnVision peroxidase/DAB kit (DakoCytomation) according the protocol provided by the manufacturer. Haematoxilin counterstaining was also done. Negative controls were performed by either 1) substitution of anti-GH receptor with mouse IgG1 negative control (DakoCytomation) or antibody dilution buffer, or 2) alternative omission of the other essential steps of the immunoreaction.

These immunohistochemical studies showed GH receptor positivity in both tumors. Specifically, the papillary carcinoma cells showed intense and diffuse immunoreactivity (Fig. 1A, 1C). No immunostaining was observed in the controls performed to ascertain the specificity of the immunoreaction (Fig. 1B, 1D).

\section{Discussion}

In this study, we report two unrelated children patients with TS in which papillary thyroid carcinoma was detected during (Patient 1) or several years after (Patient 2) GH treatment. To our knowledge, this is the first report of papillary thyroid carcinoma in children with TS that have been treated with GH.

We cannot rule out the possibility that the papillary thyroid carcinoma and TS observed in these patients were independent pathologies that arose coincidentally. However, the probability of co-occurrence of these disorders in a single patient is very low, particularly in Patient 1, given that early onset of this carcinoma is extremely rare. Specifically, the absolute risks of diverse neoplasms have been found to be insignificantly raised in TS (odds ratio 1.35 or less), except for gut cancer (particularly colon and rectum) and gonadoblastoma in
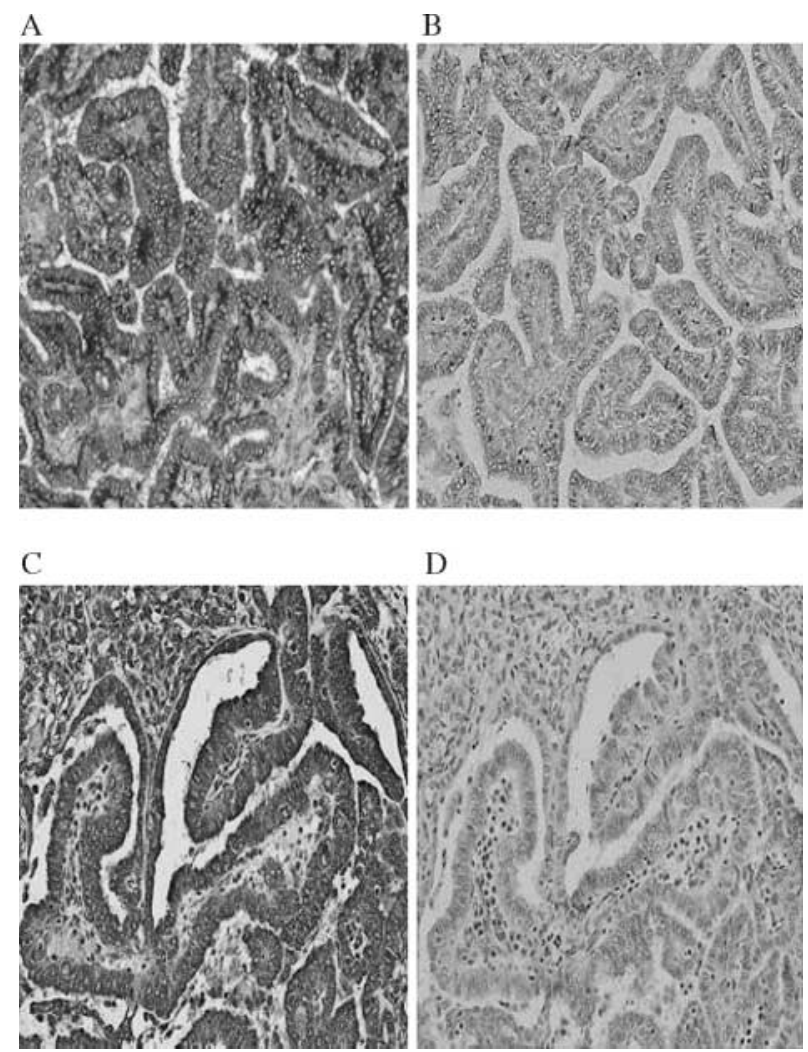

D

Figure 1 (A) Case 1. GH receptor immunostaining in the papillary carcinoma cells was strong, primarily on the basal side of the cells. (B) The control performed by substitution of the primary antibody with mouse IgG1 negative control was not immunostained; Original magnification: $\times 20$. (C) Case 2 . GH receptor positivity was intense and diffuse. (D) The control performed in a serial section by substitution of the primary antibody with buffer did not show immunoreactivity (D). Original magnification: $\times 20$. 
patients with occult Y chromosome sequences $(1,3)$. In addition, there have been no previous reports of the association between TS and papillary thyroid carcinoma, although there has been one report of an anaplastic thyroid carcinoma in a TS patient, in association with Hashimoto's thyroiditis (9). Patients with Hashimoto's thyroiditis have a higher risk of thyroid malignancies such as papillary thyroid carcinoma (10).

Numerous epidemiological studies and studies based on exhaustive long-term monitoring of GH-treated patients have found $\mathrm{GH}$ treatment to be therapeutically beneficial, safe (11), and with no detectable effect on the risk of cancer (12). However, recent studies have indicated a possible relationship between the GH-IGF axis and the pathogenesis of neoplasms (13). GH is involved in growth, development and survival, with diverse effects on cell proliferation and differentiation; it is also a strong inhibitor of apoptosis. IGF-I is the main mediator of GH, synthesized in almost all tissues. Its effects are mediated by the IGF-I receptor (IGFIR) and regulated by several molecules (14). There is in vitro and in vivo evidence of over-expression of IGF-1 and IGFIR in tumor cells. A growing number of epidemiological studies suggest that an increase in IGF-1, alterations of IGF-I-binding proteins and/or IGF-1 misregulation may be risk factors for cancer. The association of these factors with breast, prostate, colon (4) and other carcinomas has been noted in several studies (5). A decrease in IGF-I level induced by restricted diet in mice with tumors was associated with a decline in DNA synthesis and increased tumor cell apoptosis, and thus slowed tumor progression (15). A recent report has described a common polymorphism in the human GH gene that is associated with reduced concentrations of GH and IGF-I, and inversely associated with colorectal cancer risk (16).

In this context, in patients with acromegaly (characterized by high GH levels and circulating concentrations of IGF-I at the high end of the normal range), an increased risk of epithelial cancers has been reported (17-19), as well as the association with papillary thyroid carcinoma $(20,21)$.

The apparent association between IGF-I levels and cancer is heterogeneous, and potential mechanisms of the putative effect are still unknown, thus there is a clear need for systematic studies. However, we consider that the putative carcinogenic potential of $\mathrm{GH}$ is plausible, since several types of carcinoma (including the papillary thyroid carcinomas considered in the present study) express GH receptors. GH receptor immunoreactivity has also been reported in other tumor types, such as hepatocellular carcinoma (22) and occasionally in tumors appearing after GH therapy in immunocompromised patients (23). In our cases we found intense diffuse immunoreactivity in papillary carcinoma cells, though note that $\mathrm{GH}$ receptors have also been detected in normal thyroid cells of chickens (24), humans and rats (25). Other studies have also demonstrated the presence of the IGF-1 receptor in thyroid papillary carcinomas (26). In any case, diverse growth factors may play important roles in the growth and progression of these carcinomas (27-29).

In conclusion, we have here presented the first reports of papillary thyroid carcinoma after GH therapy for TS, in two patients. Although we cannot rule out the possibility of a non-causal coincidental association, in our opinion our results raise the possibility that under some circumstances $\mathrm{GH}$ treatment may have effects unknown to us. In view of this, we consider that prospective long-term studies are required to assess the possible effects of $\mathrm{GH}$ treatment on cancer risk (4). Previous studies of possible relationships between $\mathrm{GH}$ treatment and cancer have mainly considered the adult population, in view of the higher prevalence of cancer among adults. The long-term effect of high IGF-I levels remains to be investigated. We would highlight the need for strict monitoring from childhood onwards, in view of the very early onset of papillary thyroid carcinoma in our first patient. Continued follow-up of these children is imperative.

\section{Acknowledgements}

This study was supported in part by the Xunta de Galicia (grant number PGIDIT02PXIB20801PR) and FIDEP (Fundación para la Investigación y Desarrollo de la Endocrinología Pediátrica).

\section{References}

1 Gravholt $\mathrm{CH}$. Epidemiological, endocrine and metabolic features in Turner syndrome. European Journal of Endocrinology 2004 $151657-687$.

2 Medeiros CC, Marini SH, Baptista MT, Guerra G Jr \& MacielGuerra AT. Turner's syndrome and thyroid disease: a transverse study of pediatric patients in Brazil. Journal of Pediatric Endocrinology and Metabolism 200013 357-362.

3 Gravholt CH, Fedder J, Naeraa RW \& Muller J. Ocurrence of gonadoblastoma in females with Turner syndrome and Y chromosome material: a population study. Journal of Clinical Endocrinology and Metabolism 2000 85 3199-3202.

4 Moschos SJ \& Mantzoros CS. The role of the IGF system in cancer: from basic to clinical studies and clinical applications. Oncology 200263 317-332.

5 Cohen P, Clemmons DR \& Rosenfeld RG. Does the GH-IGF axis play a role in cancer pathogenesis? Growth Hormone IGF Research $200010297-305$.

6 Chang YS, Gong K, Sun S, Liu D, El-Naggar AK, Khuri FR, Hong WK \& Lee HY. Clinical significance of insulin-like growth factor-binding protein-3 expression in stage I non-small cell lung cancer. Clinical Cancer Research 200223 824-854.

7 LeRoith D. Emerging concepts in the role of IGFs and cancer. Hormone and Metabolism Research 200335 649-650.

8 Franceschi S, Boyle P, Maisonneuve P, La Vecchia C, Burt AD, Kerr DJ \& McFarlane GJ. The epidemiology of thyroid carcinoma. Critical Review of Oncogenesis $1993425-52$.

9 Wertelecki W, Fraumeni TF Jr \& Mulvihill JJ. Nongonadal neoplasia in Turner's syndrome. Cancer $1970 \mathbf{2 6} 485-488$.

10 Wirtschafter A, Schmidt R, Rosen D, Kundu N, Santoro M, Fusco A, Multhaupt H, Atkins JP, Rosen MR, Keane WM \& Rothstein JL. 
Expression of RET/PTC fusion gene as a marker for papillary carcinoma in Hashimoto's thyroiditis. Laryngoscope 1997107 95-100.

11 Ranke MB, Partsch CJ, Lindberg A, Dorr HG, Bettendorf M, Hauffa BP, Schwarz HP, Mehls O, Sander S, Stahnke N, Steinkamp H, Said E \& Sippell W. Adult height after GH therapy in 188 Ullich-Turner syndrome patients: results of the German IGLU Follow-up Study 2001. European Journal of Endocrinology $2002147625-633$.

12 Growth Hormone Research Society, Critical evaluation of the safety of recombinant human growth hormone administration: statement. Journal of Clinical Endocrinology and Metabolism 2001 86 1868-1870.

13 Swerdlow AJ, Higgins CD, Adlard P \& Perece MA. Risk of cancer in patients treated with human pituitary growth hormone in the UK 1959-1985: a cohort study. Lancet $2002360273-277$.

14 Furstenberger G \& Senn HJ. Insulin-like growth factors and cancer. Lancet Oncology 20023 298-302.

15 Dunn SE, Kari FW, French J, Leininger JR, Travlos G \& Wilson R. Dietary restriction reduces insulin-like growth factor I levels, which modulates apoptosis, cell proliferation, and tumor progression in p53-deficient mice. Cancer Research $1997 \mathbf{5 7}$ $4667-4672$.

16 Le Marchand L, Donlon T \& Seifried A. Association of a common polymorphism in the human $\mathrm{GH} 1$ gene with colorectal neoplasia. Journal of National Cancer Institute 200294 454-460.

17 Baris D, Gridley G, Ron E, Weiderpass E, Mellemkjaer L, Ekbom A, Oslen JH, Baron JA \& Fraumeni JF Jr. Acromegaly and cancer risk: a cohort study in Sweden and Denmark. Cancer Causes Control $200213395-400$.

18 Gasperi M, Martino E, Manetti L, Arosio M, Porretti S, Faglia G, Mariotti S, Colao AM, Lombardi G, Baldelli R, Camanni F \& Liuzzi A. Acromegaly Study Group of the Italian Society of Endocrinology. Journal Endocrinology Investigation 200225 930-931.

19 Orme SM, McNally RJ, Cartwright RA \& Belchetz PE. Mortality and cancer incidence in acromegaly: a retrospective cohort study. United Kingdom Acromegaly Study Group. Journal of Clinical Endocrinology and Metabolism $1998 \mathbf{8 3} 2730-2734$.
20 Oppenheim Y, Yeh HC, Brandwein M \& Tomer Y. Thyroid carcinoma in a patient with acromegaly. Thyroid 200111 1197-1198.

21 Balkany C \& Cushing GW. An association between acromegaly and thyroid carcinoma. Thyroid 19955 47-50.

22 Garcia Caballero T, Mertani HM, Lambert A, Gallego R, Fraga M, Pintos E, Forteza J, Chevallier M, Lobie PE, Vonderhaar BK, Beiras A \& Morel G. Increased expression of growth hormone and prolactin receptors in hepatocellular carcinomas. Endocrine 200012 265-271.

23 Pantanowitz L, García-Caballero T \& Dezube BJ. Growth hormone receptor $(\mathrm{GH})$-expressing carcinoid tumors after recombinant human GH therapy for human immunodeficiency virus-related lipodystrophy. Clinical Infectious Diseases 200336 370-372.

24 Hull KL, Janssens WC, Baumbach WR \& Harvey S. Thyroid glands: novel sites of growth hormone action. Journal of Endocrinology $1995146449-458$.

25 Blanco M, Bravo S, Garcia-Caballero T, Alvarez CV, Gallego R, Lambert A, Morel G, Dieguez C \& Beiras A. Localization of growth hormone receptors in rat and human thyroid cells. Cell Tissue Research 2001306 423-428.

26 Vella V, Sciacca L, Pandini G, Mineo R, Squatrito S, Vigneri R \& Belfiore A. The IGF system in thyroid cancer: new concepts. Molecular Pathology 200154 121-124.

27 Farid NR, Shi Y \& Zou M. Molecular basis of thyroid cancer. Endocrine Reviews $199415202-232$.

28 Vella V, Pandini G, Sciacca L, Mineo R, Vigneri R, Pezzino V \& Belfiore A. A novel autocrine loop involving IGF-II and the insulin receptor isoform-A stimulates growth of thyroid cancer. Journal of Clinical Endocrinology and Metabolism 200287 245-254.

29 Kanamori A, Abe Y, Yajima Y, Manabe Y \& Ito K. Epidermal growth factor receptors in plasma membranes of normal and disease human thyroid glands. Journal of Clinical Endocrinology and Metabolism $1989 \mathbf{6 8} 899-903$.

Received 25 February 2005

Accepted 24 June 2005 